Pre-print of: Recillas, S. et al. "Use of $\mathrm{CeO}_{2}, \mathrm{TiO}_{2}$ and $\mathrm{Fe}_{3} \mathrm{O}_{4}$ nanoparticles for the removal of lead from water. Toxicity of nanoparticles and derived compounds" in Desalination (Ed. Elsevier), vol. 277, issues 1-3 (Aug. 2011), p. 213-220. The final version is available at DOI 10.1016/j.desal.2011.04.036

\title{
Use of $\mathrm{CeO}_{2}, \mathrm{TiO}_{2}$ and $\mathrm{Fe}_{3} \mathrm{O}_{4}$ nanoparticles for the removal of lead from water.
}

Toxicity of nanoparticles and derived compounds.

Sonia Recillas ${ }^{1}$, Ana García ${ }^{1}$, Edgar González ${ }^{2}$, Eudald Casals ${ }^{2}$, Victor Puntes ${ }^{2,3}$, Antoni Sánchez ${ }^{1, *}$, Xavier Font ${ }^{1}$

1. Department of Chemical Engineering, Escola d'Enginyeria, Universitat Autònoma de Barcelona, 08193 Bellaterra, Spain

2. Institut Català de Nanotecnologia, Campus de la Universitat Autònoma de Barcelona, 08193 Bellaterra, Spain

3. Insitut Català de Recerca i Estudis Avançats, Passeig Lluís Companys, 23, 08010 Barcelona, Spain

*Corresponding author: Antoni Sánchez

Phone: 34-935811019

Fax: $\quad 34-935812013$

E-mail address: antoni.sanchez@uab.cat 


\begin{abstract}
Nanoparticles (NPs) suspensions of $\mathrm{CeO}_{2}, \mathrm{Fe}_{3} \mathrm{O}_{4}$ and $\mathrm{TiO}_{2}$ were synthesized and tested for lead removal in water cleaning processes. The results obtained are promising for the use of these NPs in lead elimination via adsorption process. The adsorption capacity obtained for the NPs was: $189 \mathrm{mg} \mathrm{Pb} / \mathrm{g} \mathrm{NPs} \mathrm{CeO}_{2}, 83 \mathrm{mg} \mathrm{Pb} / \mathrm{g} \mathrm{NPs} \mathrm{Fe}_{3} \mathrm{O}_{4}$ and $159 \mathrm{mg} \mathrm{Pb} / \mathrm{g} \mathrm{NPs} \mathrm{TiO}_{2}$. Another important issue assessed in this study was to determine the toxicity of the NPs in each step of the process: synthesized NPs, NPs after lead adsorption and the supernatant after NPs separation. In order to study the interaction with living organisms and prevent future environmental damages, the Germination test in Tomato (Lycopersicom esculentum), Lettuce (Lactuca sativa), Cucumber (Cucumis sativus) seeds and the Microtox ${ }^{\circledR}$ assay, based on the use of bioluminescent marine bacterium, Photobacterium phosphoreum/Vibrio fischeri, were used to evaluate the toxicity of these materials. The $\mathrm{CeO}_{2} \mathrm{NPs}$ showed a high level of lead removal although presented a high phytotoxicity. The $\mathrm{TiO}_{2} \mathrm{NPs}$ inhibited the lead toxicity against the marine bacterium. Interestingly, the media used to stabilize the NPs (tetramethylammonium hydroxide and hexamethylenetetramine) presented a significant reduction in the germination index. $\mathrm{TiO}_{2}$ and $\mathrm{Fe}_{3} \mathrm{O}_{4}$ NPs did not exhibit any toxicity and could be used as absorbents for $\mathrm{Pb}$ (II) removal.
\end{abstract}

Keywords: Lead adsorption; Nanoparticles; Toxicity; Phytotoxicity; Water Treatment. 


\section{Introduction}

The use of nanoparticles (NPs) for water treatment processes is now a reality: a long list of materials based on nanostructures are today in the market or under final research steps [1], even though the worldwide tendency to decrease the permitted level of contamination in drinking water is a big challenge for the environmental researchers [2]. In the case of lead contamination, the toxicity and poisoning by lead in numerous areas are well documented [3,4]. Many methods have been used to remove $\mathrm{Pb}$ (II) from water and waste-water, mainly by chemical precipitation, ionic exchange, membrane separation, biosorption, adsorption process, etc. However, most of them require an extensive processing and present a high cost. It is therefore necessary to develop more

efficient remediation strategies that are able to remove $\mathrm{Pb}$ (II) from contaminated water at high concentrations [5].

The main advantage of using NPs materials compared to conventional materials is the high surface area, which means a large space for the development of chemical reactions, physic interchanges, etc. [6]. Nevertheless, the use of these materials in any application has to consider this high surface reactivity in order to prevent possible ecological damage. In recent years, substantial attention has been paid to the environmental damage evaluation [7,8], although a lot of answers about the NPs toxic effects are still unknown [9]. The toxicity of a considerable number of NPs used for water treatment has been reported in the literature using different methodologies [10,11], although the complete removal process in which the NPs are involved (i.e. adsorption, ionic exchange, etc.) and the physicochemical and structural changes during the process have not been exhaustively studied. The effects and toxicity mechanisms of NPs on plants have been in fact poorly studied [12,13]. Other important issue is the 
difficulty to compare the adsorption capacity of nanomaterials reported in the literature because the experimental reaction conditions and the surface chemistry of NPs are not always the same [14].

In the present work, the adsorption capacity at different lead concentrations, the kinetic adsorption behavior at $100 \mathrm{mg} / \mathrm{ml}$ of lead concentration in front of $\mathrm{CeO}_{2}, \mathrm{TiO}_{2}$ and $\mathrm{Fe}_{3} \mathrm{O}_{4}$ NPs suspensions at the same concentration $(320 \mathrm{mg} / \mathrm{l})$ and similar order of particle size have been studied. The toxicity of the initial $\mathrm{CeO}_{2}, \mathrm{Fe}_{3} \mathrm{O}_{4}$ and $\mathrm{TiO}_{2} \mathrm{NPs}$ suspensions, the NPs after lead adsorption process separated by centrifugation and the water remaining after NPs separation were evaluated by the bioluminescent bacteria test (Microtox) and the germination test as standard toxicity tests.

\section{Materials and Methods}

\subsection{Synthesis of Nanoparticles (NPs)}

Different kinds of metallic and metal oxide NPs were synthesized in aqueous phase, using milli-Q grade water. All reagents were purchased from Sigma-Aldrich and used as received. All the synthesis procedures are based on preexisted ones available in the scientific literature with modifications to be adapted to large-scale yields. For $\mathrm{CeO}_{2}$ NPs, a method based on Zhang et al. [15] was used. The $\mathrm{Ce}^{3+}$ ions from $\mathrm{Ce}\left(\mathrm{NO}_{3}\right)_{3}$ salt were oxidized at basic $\mathrm{pH}$ conditions to $\mathrm{Ce}^{4+}$ using Hexamethylenetetramine (HMT). Then, the $\mathrm{CeO}_{2}$ nanocrystals precipitate and are further stabilized in aqueous solution with the same reagent (HMT), which forms the double electrical layer to prevent NPs agglomeration.

For the synthesis of $\mathrm{TiO}_{2}$, the process of Pottier et al. [16] was used. The synthesis procedure consists on the decomposition of Titanium Tetrachloride $\left(\mathrm{TiCl}_{4}\right)$ at acidic $\mathrm{pH}$ (from 2 to 6 ). After this, it follows a growing step of the nanocrystals, carried 
out in an oven at $70^{\circ} \mathrm{C}$, a purification step by centrifugation and a resuspension with tetramethylammonium hydroxide (TMAOH) to stabilize the NPs. Depending on the $\mathrm{pH}$ used during the growing step, the obtained size and shape of the $\mathrm{TiO}_{2}$ varies from small size and spherical-like NPs (from $5 \mathrm{~nm}$, not used in this work) to bigger particles (around $10 \mathrm{~nm}, \mathrm{pH}=5$, used in this work).

For $\mathrm{Fe}_{3} \mathrm{O}_{4}$ NPs, they were synthesized by a modified method based on Massart's method [17,18]: amounts of $1 \mathrm{mmol}$ iron (II) chloride $\left(\mathrm{FeCl}_{2}\right)$ and $2 \mathrm{mmol}$ iron (III) chloride $\left(\mathrm{FeCl}_{3}\right)$ were dissolved in $50 \mathrm{~mL}$ deoxygenated water and then added dropwise to $50 \mathrm{~mL}$ of a solution of $1 \mathrm{M}$ deoxygenated $\mathrm{TMAOH}$. After $30 \mathrm{~min}$ of vigorous stirring under a $\mathrm{N}_{2}$ stream, the $\mathrm{Fe}_{3} \mathrm{O}_{4}$ precipitate was washed by soft magnetic decantation and redissolved in $1 \mathrm{mM}$ TMAOH to obtain the final stable colloidal solution of $\mathrm{Fe}_{3} \mathrm{O}_{4} \mathrm{NPs}$. Table 1 shows the main characteristics of the NPs used in this work.

\subsection{Characterization and stability of NP}

All NPs were characterized using different techniques: Transmission Electron Microscopy (TEM), Zeta Potential (Z-Potential), Dynamic Light Scattering (DLS) and X-Ray Diffraction (XRD). TEM images were acquired with a JEOL 1010 Electron Microscope operating at an accelerating voltage of $80 \mathrm{kV}$. Samples for TEM were prepared by drop casting on carbon coated cooper TEM grids and left solvent evaporate at room temperature. Afterwards, more than 500 particles from different images were computer-analyzed and measured for size distribution analysis.

Z-Potential and DLS measurements were made with a Malvern ZetaSizer Nano ZS Instrument operating at a light source wavelength of $532 \mathrm{~nm}$ and a fixed scattering angle of $173^{\circ}$ for detection. Aliquots of $0.8 \mathrm{ml}$ of the colloidal NPs solutions were placed into the specific cuvette and the software was arranged with the specific 
parameters of refractive index and absorption coefficient of NP material and solvent viscosity (data required to obtain the correct value for each NP type). Z-Potential is a commonly used tool to determine the stability of a colloidal suspension of electrostatically stabilized NPs as the ones used in this work. DLS allows the determination of the hydrodynamic diameter of colloidal particles, which is the diameter of the sphere with the same Brownian motion as the analyzed particle, and is also used to check for the presence of agglomerates.

X-Ray Diffraction (XRD) spectra were acquired with a PANalytical X'Pert diffractometer that uses a $\mathrm{Cu} \mathrm{K} \alpha$ radiation source. Samples for XRD consist of the dry NPs in powder form. For this purpose, NPs were extracted out of the colloid through centrifugation and recovering and drying the pelleted powder NPs (Table 1 and Fig. 1).

\section{3. $\mathrm{Pb}^{2+}$ Adsorption studies}

The adsorption kinetics and the adsorption capacity (qe) at equilibrium of $\mathrm{Fe}_{3} \mathrm{O}_{4}$, $\mathrm{TiO}_{2}$ and $\mathrm{CeO}_{2} \mathrm{NPs}$ synthesized at room temperature and $\mathrm{pH}=7$ were performed by the following procedure. A solution of $200 \mathrm{mg} / \mathrm{l}$ of $\mathrm{Pb}^{2+}$ was prepared by dissolving the required amount of $\mathrm{Pb}\left(\mathrm{NO}_{3}\right)_{2}$ in deionized water.

The NPs of $\mathrm{Fe}_{3} \mathrm{O}_{4}$ and $\mathrm{TiO}_{2}$ were diluted in deionized water to obtain the same concentration of $\mathrm{CeO}_{2}$ NPs $(640 \mathrm{mg} / \mathrm{l})$. The $\mathrm{pH}$ of each NPs suspension was adjusted at 7 using sodium hydroxide $0.1 \mathrm{M}\left(\mathrm{CeO}_{2} \mathrm{NPs}\right)$ and citric acid $0.1 \mathrm{M}\left(\mathrm{Fe}_{3} \mathrm{O}_{4} \mathrm{NPs}\right.$ and $\mathrm{TiO}_{2}$ NPs). Then $25 \mathrm{ml}$ of lead solution $(200 \mathrm{mg} / \mathrm{l})$ was poured in a bottle and afterwards, 25 $\mathrm{ml}$ of each NPs suspension was added drop by drop to the bottle. Finally, the suspension was continuously stirred at $150 \mathrm{rpm}$ at room temperature. The samples obtained at different times were centrifuged. The lead concentration from the liquid phase was determined by a standard colorimetric method [19]. Experiments were carried out in 
triplicate and the average values are presented. Standard deviation values were always lower than $4 \%$. From this solution the other ones were prepared by doing the appropriated dilutions.

\section{4. $\mathrm{Pb}^{2+}$ Adsorption isotherm experiments}

The adsorption isotherm experiments were carried out with lead solutions at different initial $\mathrm{Pb}^{2+}$ concentrations $\left(3.4 \mathrm{mg} / 1 \mathrm{~Pb}^{2+}, 8.5 \mathrm{mg} / 1 \mathrm{~Pb}^{2+}, 17 \mathrm{mg} / \mathrm{l} \mathrm{Pb}{ }^{2+}\right)$ at $\mathrm{pH} 7$ and at room temperature (Table 2). The experimental procedure was the same used to obtain the adsorption kinetics. The initial and final lead concentration from the liquid phase was determined by a standard colorimetric method. To assure the equilibrium and guarantee the full adsorption, the NPs suspensions were centrifuged after $24 \mathrm{~h}$ of adsorption time. The equilibrium time is in agreement with other reports [20] for the adsorption of lead by magnetic nanoadsorbents and for the adsorption of others metal ions onto iron oxide nanoparticles [21-23].

\subsection{Bioluminescent test}

A commercial Microtox Analyzer model 500 from Azur Environmental was used. Whole Effluent Toxicity (WET) test protocol was used to determine the toxicity of the initial lead solution $(2.5 \mathrm{mg} / \mathrm{l})$, the initial NPs suspensions of $\mathrm{CeO}_{2}, \mathrm{Fe}_{3} \mathrm{O}_{4}, \mathrm{TiO}_{2}$ of $320 \mathrm{mg} / \mathrm{l}$ and the final suspension obtained after $3 \mathrm{~h}$ of adsorption process at $\mathrm{pH} 7$ and at room temperature.

The Microtox test is based on the percentage of decrease in the amount of light emitted by the bioluminescent marine bacterium Vibrio fischeri (Photobacterium phosphoreum) [24,25]. The light emitted reduction is directly related to the relative toxicity of the sample. For the three suspensions the half maximal inhibitory 
concentration (IC50) was calculated. IC50 is a measure of the effectiveness of a compound in inhibiting biological or biochemical functions and it was obtained from plotting the percentage of luminescence reduction against concentration after $15 \mathrm{~min}$ incubation time. It is considered that if IC50 $(\%) \leq 25$ the suspension is highly toxic; within $25-50$ the suspension is moderately toxic; within $51-75$ the suspension is toxic; for values higher than 75 the suspension is slightly toxic and for values higher than 100 the suspension is non-toxic [26]. The experimental procedure has been adopted from the official standards of several countries [27,28].

The NPs synthesized (NPs Fe, NPs Ce, NPs Ti), the NPs after $24 \mathrm{~h}$ adsorption process ( $\mathrm{NPs} \mathrm{Fe}+\mathrm{Pb}$, NPs $\mathrm{Ce}+\mathrm{Pb}$, NPs $\mathrm{Ti}+\mathrm{Pb}$ ), the liquid obtained after the NPs centrifugation (liquor NPs Fe, liquor NPs Ce, liquor NPs Ti) and the initial lead solution (2.5 mg/l) were evaluated following the Microtox test.

Toxicity tests for stabilizer samples and NPs suspensions samples were performed in triplicate. $\mathrm{pH}$ of stabilizers and NPs suspension samples was previously adjusted to 7 . No visible precipitate was observed during the adjustment.

\subsection{Seed germination test}

The phytotoxicity of the NPs used for the adsorption studies $\left(\mathrm{CeO}_{2}, \mathrm{TiO}_{2}\right.$, $\mathrm{Fe}_{3} \mathrm{O}_{4}$ ), the NPs after adsorption process (NPs plus $\mathrm{Pb}$ ), the liquid obtained after the NPs centrifugation (NPs plus $\mathrm{Pb}$ adsorption resulting liquor), the medium containing the stabilizer, a pure medium used with $2.5 \mathrm{mg} / \mathrm{l}$ lead solution (medium plus $\mathrm{Pb}$ ) and deionized water as a control was evaluated by the germination test on Tomato (Lycopersicom esculentum), Lettuce (Lactuca sativa) and Cucumber (Cucumis sativus) seeds. The experiments were performed at $25^{\circ} \mathrm{C}(\mathrm{pH}=7)$ in triplicate.

Twenty seeds of tomato, twenty seeds of lettuce and ten seeds of cucumber were 
evaluated using the germination test described by Tiquia et al. [29]. $4 \mathrm{ml}$ of the NPs suspension or solutions tested were poured in Petri dishes with a Whatman $\mathrm{N}^{\circ} 1$ filter paper. The experiments were performed in the dark. After 5 incubation days, the seed germination, the root elongation and the germination index were determined. Each of experimental values was compared with its corresponding control. All the statistical analysis was performed using the software SPSS 17.0 (SPSS Inc., Chicago, USA). Statistical significance was considered for a confidence level of $95 \%$ in all the statistical analyses. Relative root elongation (E) and germination index (GI) were calculated according to standard methods [30], as reported below:

$\mathrm{GI}=(\%$ seed germination $)(\%$ root elongation $) / 100$

where:

$\%$ seed germination $=($ Seeds germinated with NPs $) /($ Seeds germinated with control)x 100

$\%$ root elongation $(\mathrm{E})=$ (Mean root length with NPs)/(Mean root length with control)x 100

\section{Results and discussion}

\subsection{Nanoparticles characterization}

The morphology and size distribution of nanoparticles were characterized by TEM (Fig. 1). TEM image of $\mathrm{CeO}_{2}$ nanoparticles with octahedral morphology and XRD pattern are shown. The diffraction peaks are corresponding to the (111), (200), (220), (311), (222), (400), (331) and (420) planes for the cubic fluorite structure of $\mathrm{CeO}_{2}$. The average diameter of nanoparticles is $12.4 \mathrm{~nm}$. In the case of $\mathrm{TiO}_{2}$ nanoparticles, TEM 
image (Fig. 1) indicates that the average size of NPs is about $7.6 \mathrm{~nm}$ and the shape of product is amorphous. XRD pattern shows the diffraction peaks corresponding to the (111), (101), (111), (210), (211), (220), (002), (301) and (112) planes, respectively. Finally, TEM image of $\mathrm{Fe}_{3} \mathrm{O}_{4}$ nanoparticles shows an average diameter of $7.8 \mathrm{~nm}$ whereas XRD pattern presents the diffraction peaks in (220), (311), (400), (422), (511) and (400) planes, which correspond to the standard pattern of $\mathrm{Fe}_{3} \mathrm{O}_{4}$. In general, all the nanoparticles show an irregular morphology.

Other general characteristics of the nanoparticles used in this study are presented in Table 1. In this Table, it is important to emphasize to value of the Z-potential to compare it with other published works, since these parameter is strongly affected by the media used to stabilize the nanoparticles and to prevent their agglomeration, a point that is not often considered when working with commercial nanoparticles powders $[2,24]$.

\subsection{Adsorption Kinetics}

The adsorption evolution obtained for $\mathrm{TiO}_{2}, \mathrm{Fe}_{3} \mathrm{O}_{4}$ and $\mathrm{CeO}_{2} \mathrm{NPs}$ is shown in Fig. 2. In the case of $\mathrm{Fe}_{3} \mathrm{O}_{4}$ and $\mathrm{CeO}_{2} \mathrm{NPs}$, the maximum adsorption was reached almost immediately at the first measure (15 minutes), while the maximum adsorption in the case of $\mathrm{TiO}_{2}$ NPs was reached after an oscillation period of adsorption-desorption (being this oscillation behavior close to the analytical method precision). After around $10 \mathrm{~h}$ the three systems reached equilibrium and were stable with time. The percentages of removal after $24 \mathrm{~h}$ of adsorption and $100 \mathrm{mg} / \mathrm{l} \mathrm{Pb}^{2+}$ of initial concentration were: $58 \%$ for $\mathrm{CeO}_{2}, 49 \%$ for $\mathrm{TiO}_{2}$ and $26 \%$ for $\mathrm{Fe}_{3} \mathrm{O}_{4}$. Experiments at different initial $\mathrm{Pb}^{2+}$ concentration were performed to evaluate the adsorption capacities of the NPs studied. The sorption equilibrium capacity $\left(\mathrm{q}_{\mathrm{e}}\right)$ of the adsorbed $\mathrm{Pb}^{2+}$ was calculated according to the following equation: 


$$
\mathrm{q}_{\mathrm{e}}=\left(\mathrm{C}_{0}-\mathrm{C}_{\mathrm{e}}\right) \mathrm{V} / m
$$

where: $\mathrm{C}_{0}$ and $\mathrm{C}_{\mathrm{e}}$ represent the initial and equilibrium metal ion concentration $(\mathrm{mg} / \mathrm{l})$, respectively; $\mathrm{V}$ is the volume of the metal ion solution $(\mathrm{mL})$, and $m$ is the amount of adsorbent (mg) (Table 2).

The sorption equilibrium capacity $\left(\mathrm{q}_{\mathrm{e}}\right)$ obtained for $95 \mathrm{mg} / \mathrm{l}$ initial concentration of $\mathrm{Pb}^{2+}$ were: $181.2 \mathrm{mg} \mathrm{Pb} / \mathrm{g}$ NPs $\mathrm{CeO}_{2}, 153.24 \mathrm{mg} \mathrm{Pb} / \mathrm{g} \mathrm{NPs} \mathrm{TiO}_{2}$ and $81.6 \mathrm{mg}$ $\mathrm{Pb}^{2+} / \mathrm{g}$ NPs $\mathrm{Fe}_{3} \mathrm{O}_{4}$ (Table 2). The $\mathrm{Fe}_{3} \mathrm{O}_{4}$ NPs completely removed the $\mathrm{Pb}^{2+}$ up to $17 \mathrm{mg} / \mathrm{l}$ $\mathrm{Pb}^{2+}$, the $\mathrm{CeO}_{2} \mathrm{NPs}$ removed completely the $\mathrm{Pb}^{2+}$ up to $8.5 \mathrm{mg} / \mathrm{l}$ and the $\mathrm{TiO}_{2} \mathrm{NPs}$ up to $3.4 \mathrm{mg} / \mathrm{l}$.

In order to investigate the adsorption kinetic of $\mathrm{Pb}^{2+}$ with the nanoadsorbents, two kinetics models were applied to simulate the experimental results (pseudo-firstorder and pseudo-second-order models). The linear form of pseudo-first-order model can be expressed as:

$\log \left(\mathrm{q}_{\mathrm{e}}-\mathrm{q}_{\mathrm{t}}\right)=\log \mathrm{q}_{\mathrm{e}}-\left(\mathrm{k}_{1} / 2.303\right) \mathrm{t} \quad$ Eq. (2)

where: $\mathrm{q}_{\mathrm{e}}$ and $\mathrm{q}_{\mathrm{t}}(\mathrm{mg} / \mathrm{g})$ are the amounts of the metal ions adsorbed at equilibrium $(\mathrm{mg} / \mathrm{g})$ and at time $\mathrm{t}(\mathrm{h})$, respectively, and $\mathrm{k}_{1}$ is the pseudo-first-order rate constant $\left(\mathrm{h}^{-1}\right)$. The adsorption rate constant $\left(\mathrm{k}_{1}\right)$ can be determined experimentally by plotting $\log$ $\left(q_{e}-q_{t}\right)$ versus $t$. The correlation coefficient values $R^{2}$ obtained plotting the log $\left(q_{e}-q_{t}\right)$ versus $t$ for each NPs experiment data was very low $\left(\mathrm{NPs} \mathrm{TiO}_{2} 0.6914, \mathrm{NPs}^{\mathrm{CeO}} \mathrm{Ce}_{2}\right.$ 0.5166, $\mathrm{NPs} \mathrm{Fe}_{3} \mathrm{O}_{4}$ 0.2911). These results suggest that the adsorption of $\mathrm{Pb}^{2+}$ onto the NPs studied did not follow pseudo-first order-kinetics. 


\subsection{Pseudo-second-order kinetic model}

In recent years, the pseudo-second-order rate expression has been widely applied to the adsorption of pollutants from aqueous solutions [31]. In consequence, a pseudosecond-order model based on the assumption that the rate limiting step are the chemical sorption involving valence forces through sharing or the exchange of electrons between sorbent and sorbate [32] was used as kinetic model. The kinetics of the sorption reaction has been described as a function of the sorption equilibrium capacity $\left(\mathrm{q}_{\mathrm{e}}\right)$, the initial metal ion concentration, the adsorbent dose and the nature of the solute ion.

The pseudo-second-order rate constants $\left(\mathrm{k}_{2}\right)$ and the amount of $\mathrm{Pb}^{2+}$ adsorbed at equilibrium $\left(\mathrm{q}_{\mathrm{e}}\right)$ were calculated experimentally by plotting $\left(\mathrm{t} / \mathrm{q}_{\mathrm{t}}\right)$ versus $\mathrm{t}$ according to Equation 3, where $\mathrm{q}_{\mathrm{e}}$ is the amount of $\mathrm{Pb}^{2+}$ adsorbed (mg/g NPs) at equilibrium, while $\mathrm{q}_{\mathrm{t}}$ is the amount of the adsorption $(\mathrm{mg} / \mathrm{g})$ at any time $\mathrm{t}$.

$t / q_{\mathrm{t}}=1 / k_{2} q^{2} e^{+}+\left(1 / q_{e}\right) \mathrm{t}$

Eq. (3)

Fitted equilibrium adsorption capacities $\left(\mathrm{q}_{\mathrm{e}}\right)$ derived from Equation 3 are similar and in close agreement with those observed experimentally in the case of the three NPs studied (Table 3, Fig. 3). The correlation coefficient $\left(\mathrm{R}^{2}\right)$ for the pseudo-second-order kinetic model fits are: 0.991 for $\mathrm{CeO}_{2}, 0.986$ for $\mathrm{Fe}_{3} \mathrm{O}_{4}$ and 0.982 for $\mathrm{TiO}_{2}$. The differences between the experimental sorption equilibrium capacity and the value obtained by the pseudo-second-order kinetic model was less than $4 \%$ in the three cases; this suggest that lead adsorption followed pseudo-second-order kinetics and $\mathrm{Pb}$ ions were adsorbed onto the $\mathrm{CeO}_{2}, \mathrm{TiO}_{2}$ and $\mathrm{Fe}_{3} \mathrm{O}_{4}$ surface via chemical interactions. To make a comparison between adsorption capacities of NPs many variables are to be taken into account: synthesis methodology, reaction conditions, precursors used, 
stabilizers molecules, etc., which contribute to have different chemical surface groups, surface imperfections, impurities, changes in morphology nanoparticles size between others. Also the methodology used to obtain the adsorption capacities is variable. Even though, a rough comparison between the adsorption capacities of similar NPs could be done. Nashaat and Nassar [20] reported a maximum adsorption capacity of $\mathrm{Pb}^{2+}$ onto Iron Oxide Nanoparticles equal to $36 \mathrm{mg} / \mathrm{g}$ for particles size between $20-30 \mathrm{~nm}$. The high adsorption capacity obtained by the $\mathrm{Fe}_{3} \mathrm{O}_{4}$ nanoparticles synthesized $(81.6 \mathrm{mg} / \mathrm{g})$ could be explained by the smaller nanoparticles size and size distribution, which allows more reactive surface sites and disorders surface regions favorable to adsorb $\mathrm{Pb}^{2+}$ (Fig. 1). Differences in adsorption capacities of $\mathrm{TiO}_{2} \mathrm{NPs}$ were observed in the literature: $\mathrm{TiO}_{2}$ rutile phase $\mathrm{q}_{\mathrm{Pb}}=2260 \mu \mathrm{g} / \mathrm{g}$, NPs diameter 5-40 nm [33] and $\mathrm{TiO}_{2}$ nanocomposites of $\mathrm{TiO}_{2} /$ multiwalled carbon nanotubes $\mathrm{q}_{\max }=137 \mathrm{mg} / \mathrm{g}$ [34]. In the case of the $\mathrm{TiO}_{2}$ NPs synthesized, the large capacity obtained could be attributed to the smaller particle size and the homogeneous size distribution (Fig. 1).

The stabilization agents are essential for the stability of the colloids and their presence in the NPs formulation could not be avoided. These ions are loosely attached to the NPs, i.e. there is no a covalent bond between the surface of NPs and the ions and thus, NPs electrostatically stabilized are recognized to have a "naked" surface and do not have a role in the adsorption process.

\subsection{Bioluminescent test results}

The bioluminescent test is broadly used to evaluate the potential harmful effects of effluents discharged into surface waters [35]. The IC50 (Table 4) obtained for the $\mathrm{Fe}_{3} \mathrm{O}_{4} \mathrm{NPs}$ suspension was $44.8 \mathrm{mg} / \mathrm{l}, \mathrm{Fe}_{3} \mathrm{O}_{4}$ NPs with lead adsorbed $(2.5 \mathrm{mg} / \mathrm{l} \mathrm{Pb}$ initial concentration) presented a value of $55 \mathrm{mg} / \mathrm{l}$ and for the liquor obtained after the 
centrifugation of the $\mathrm{Fe}_{3} \mathrm{O}_{4}$ NPs with lead adsorbed, IC50 was $144 \mathrm{mg} / \mathrm{l}$. In the case of $\mathrm{CeO}_{2} \mathrm{NPs}$ the IC50 value obtained was $35.2 \mathrm{mg} / \mathrm{l}$. IC50 for $\mathrm{NPs} \mathrm{CeO}_{2}$ with lead adsorbed was $38.7 \mathrm{mg} / \mathrm{l}$ and for the liquor obtained after the centrifugation of the $\mathrm{CeO}_{2}$ NPs with lead adsorbed was $35.2 \mathrm{mg} / \mathrm{l}$. All the measurements were obtained at $15 \mathrm{~min}$ of exposure time.

No significant changes in toxicity were observed between the NPs of $\mathrm{Fe}_{3} \mathrm{O}_{4}$ and NPs of $\mathrm{Fe}_{3} \mathrm{O}_{4}$ with lead adsorbed. The toxicity of the liquor of $\mathrm{Fe}_{3} \mathrm{O}_{4}$ with lead adsorbed evaluated after centrifugation process decreased considerably. In the case of $\mathrm{CeO}_{2} \mathrm{NPs}$ and the NPs with lead adsorbed in the structure, no significant differences were observed. These results, obtained for Fe and $\mathrm{Ce} \mathrm{NPs,} \mathrm{indicate} \mathrm{that} \mathrm{the} \mathrm{adsorbed} \mathrm{Pb}$ on the NPs does not have any toxicity effect. However, when the NPs of $\mathrm{CeO}_{2}$ with lead adsorbed were centrifuged and the liquor tested, similar toxicity was obtained. This result could be explained by the nanoparticles dissolution process that could liberate toxic compounds.

The $\mathrm{TiO}_{2}$ NPs with adsorbed lead and the liquor obtained after the centrifugation of the $\mathrm{TiO}_{2}$ NPs presented in all cases a slight diminution that were less than $40 \%$ at an interval of concentration within 19.4 to $322.5 \mathrm{mg} / \mathrm{l}$ of $\mathrm{TiO}_{2}$ NPs. These results are indicative of the non-toxic effect of $\mathrm{TiO}_{2} \mathrm{NPs}$ against the Photobacterium phosphoreum marine bacteria in accordance with several reports available in the literature related to the relatively low toxicity $[36,37]$ of $\mathrm{TiO}_{2}$ NPs. Even though the high toxicity of the lead solution (Table 4), the NPs with lead adsorbed presented no toxic effect. The $\mathrm{TiO}_{2}$ NPs has been previously used to pre-concentrate lead in river water and seawater to measure the concentration in water, although the interaction of the nanoparticle and lead was not studied [9]. The Microtox results obtained pointed out a synergic interrelation between the $\mathrm{TiO}_{2}$ NPs and the lead adsorbed, reducing the toxic effect of lead against 
Photobacterium phosphoreum bacteria (Table 4), similarly to that described for $\mathrm{Fe}_{3} \mathrm{O}_{4}$ and $\mathrm{CeO}_{2}$ NPs. Pärt and Wilmark [37] have suggested that some organisms have a low uptake of chelated metals and biological membranes that are impermeable to metalethylenediaminetetraacetic acid (EDTA) and nitrilotriacetic acid (NTA) chelates reducing the metal toxicity [37]. In this case, the complex formation on the NPs surface with the lead cation could explain the decrease in the toxicity of lead $[38,39]$.

\subsection{Seed germination tests results}

The phytotoxicity results obtained for the $\mathrm{Fe}_{3} \mathrm{O}_{4}, \mathrm{TiO}_{2}$ and $\mathrm{CeO}_{2}$ NPs tested on lettuce, cucumber and tomato are shown in Table 5. In all cases, $\mathrm{Pb}^{2+}$ concentration was $2.5 \mathrm{mg} / \mathrm{l}$

\subsection{1. $\mathrm{Fe}_{3} \mathrm{O}_{4} \mathrm{NPs}$}

Significant reduction on lettuce germination index (GI) were detected in the samples containing TMAOH medium $(61 \pm 1 \%)$ and TMAOH medium with $2.5 \mathrm{mg} / \mathrm{l}$ $\mathrm{Pb}^{2+}$ in solution $(64 \pm 2 \%)$; in the case of tomato the effect was more accentuated with $42 \pm 12 \%$ and $41 \pm 5 \%$ values of GI, respectively. In the samples containing the NPs suspension a negative effect was observed in tomato seeds for both, the NPs suspension used $(61 \pm 3 \%)$ and the NPs with lead adsorbed $(67 \pm 15 \%)$. In the case of cucumber seeds, the reduction in the germination index and root elongation was not significant in all the samples tested. The germination index of lettuce, tomato and cucumber seeds were not affected by the liquor obtained after the centrifugation process.

The negative effect obtained in the GI was associated to the root elongation decrease (Table 5). The TMAOH medium affected negatively the root elongation in tomato and lettuce seeds. In fact, the diminution in the germination index and root 
elongation can be attributed to the TMAOH medium. The $2.5 \mathrm{mg} / \mathrm{l}$ lead solution did not affect the germination index. The differences in the GI between the medium sample test and the NPs suspension can be due to a less availability of the medium molecules for chemical reactions; they formed the double electrical layer to prevent NPs agglomeration. Tomato seeds are more sensitive to the environment and the negative effects were more pronounced than the results obtained for lettuce and cucumber seeds, although they present the same trend. Racuciu et al. [40] found that low concentrations of aqueous ferrofluid (NPs coated with $\mathrm{TMAOH}$ ) stimulated plant growth while high concentrations induced inhibitory or toxic effects on the growth of young popcorn plants, but the effect of the TMAOH on these results was not studied. Barrena et al. [24] concluded that the toxic effects observed in NPs can be due to the presence of NPssolvent (stabilizers) and to the combined effect of NPs-solvent and NPs. The effect observed in the germination index is attributed exclusively to the decrease in root length; for this reason is recommended to present the root length and germination test results separated when using this type of tests.

\subsection{2. $\mathrm{TiO}_{2} \mathrm{NPs}$}

Significant reduction on lettuce germination index (GI) were detected in the samples of TMAOH medium with $2.5 \mathrm{mg} / \mathrm{Pb}^{2+}$ in solution $(74 \pm 9 \%)$ as well as in root elongation $(77 \pm 5 \%)$; slight promotion of root elongation was observed in the case of

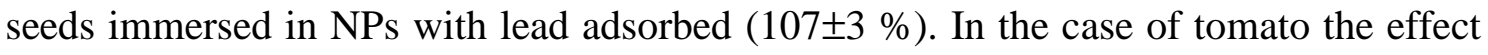
was more accentuated with $62 \pm 4 \%$ of GI for TMAOH medium, and $47 \pm 4 \%$ for solvent

and lead solution. The NPs suspension, the NPs suspension after $\mathrm{Pb}^{2+}$ adsorption and the liquor obtained after NPs separation process presented no effect on germination and root elongation test. 


\subsection{3. $\mathrm{CeO}_{2} \mathrm{NPs}$}

In the three seeds studied (Table 5), a decrease in germination index (GI) was observed mainly via root elongation diminution in tomato $(51 \pm 10 \%)$, cucumber $(63 \pm 14 \%)$ and lettuce $(75 \pm 7 \%)$. For the HMT medium, high phytotoxicity was observed for $\mathrm{CeO}_{2} \mathrm{NPs}$ suspension in tomato $(4 \pm 1 \%)$, cucumber $(1 \pm 0 \%)$ and lettuce (4 $\pm 1 \%) . \mathrm{CeO}_{2} \mathrm{NPs}$ with $\mathrm{Pb}^{2+}$ adsorption suspension showed similar results for tomato $(2 \pm 0 \%)$, cucumber $(2 \pm 1 \%)$ and lettuce $(4 \pm 1 \%)$. Liquor obtained after NPs centrifugation presented: tomato $2 \pm 0 \%$, cucumber $2 \pm 0 \%$ and lettuce $2 \pm 1 \%$. The $\mathrm{CeO}_{2}$ NPs are responsible for the high toxicity presented in the three cases; even when the NPs were centrifuged the liquor presented high toxicity. The toxic effect obtained after centrifugation process indicated the presence of a toxic compound liberated or formed in solution during the process. López-Moreno et al. [41] studied the toxic effects of nanoceria as a function of concentration, in four edible plant species. Variable phytotoxicity results were obtained: stimulated growth root in cucumber, a decreased effect in corn and tomato, relatively low toxicity on seed germination of alfalfa and cucumber and moderate toxicity on tomato and corn. These differences in the toxic effects could be attributed to the NPs synthesis method, the morphology, the surface reactivity and the molecule used as stabilizer medium, which has been observed to play an important role.

At the lead concentration analyzed $\left(2.5 \mathrm{~Pb}^{2+} \mathrm{mg} / \mathrm{l}\right)$ no phytotoxic effect was observed, although high toxicity against Photobacterium phosphoreum was previously obtained. In general the seeds of tomato were more sensible at these experimental conditions than cucumber and lettuce seeds. 


\subsubsection{Summary of germination results}

The results presented in Table 5 on the germination test emphasize that different seeds present different responses to different nanoparticles exposure. Moreover, the level of dispersion found makes these results difficult to interpret. The role of the nanoparticles stabilizer should be carefully considered. In conclusion, this kind of test does not seem suitable to have a quick evaluation of nanoparticles toxicity.

\section{Conclusions}

The adsorption capacity of $\mathrm{Pb}^{2+}$ using $\mathrm{CeO}_{2}, \mathrm{TiO}_{2}$ and $\mathrm{Fe}_{3} \mathrm{O}_{4}$ NPs was determined. The best value for these NPs of similar particle size was for $\mathrm{CeO}_{2}$. The toxic evaluation of each element evolved in the NPs stabilization and process is necessary to understand the possible impact and prevent ecological damage. The solvents/stabilizers used for the NPs stabilization showed phytotoxicity. In further NPs synthesis, the stabilization medium has to be changed to reduce this impact. Cerium NPs presented a high level of lead removal although showed a high phytotoxicity. The toxicity presented by the liquor after separation indicated a dissolution process with toxic effects to marine bacteria used in the Microtox test and in the germination test in tomato, lettuce and cucumber seeds. Further studies must be carried out to understand the phytotoxic mechanism of $\mathrm{CeO}_{2}$ NPs. The effect of the stabilizer used in NPs synthesis has also to be studied to understand these complex mechanisms. $\mathrm{TiO}_{2}$ and $\mathrm{Fe}_{3} \mathrm{O}_{4}$ NPs did not present toxicity and can be used as absorbents for $\mathrm{Pb}$ (II) removal due to the high adsorption obtained and the short adsorption time needed to achieve equilibrium. 


\section{Acknowledgements}

Financial support was provided by the Spanish Ministerio de Medio Ambiente y Medio Rural y Marino (Project Exp. 007/RN08/03.1). Sonia Recillas thanks Universitat Autònoma de Barcelona for the award of a post-doctoral fellowship. 


\section{References}

[1] B. Nowack, T.D. Bucheli, Occurrence, behavior and effects of nanoparticles in the environment, Environ. Pollut. 150 (2007) 5-22.

[2] K. Jia, B. Pan, L. Lva, Q. Zhang, X. Wang, B. Pan, W. Zhang, Impregnating titanium phosphate nanoparticles onto a porous cation exchanger for enhanced lead removal from waters, J. Colloid Interface Sci. 331 (2009) 453-457.

[3] W. Förstner, Metal Pollution in the Aquatic Environment, Springer, Berlin Heindelberg, New York, Tokyo (1984) pp. 18-20 (Chapter B: toxic metals).

[4] T. Pradeep, K.R.A. Anshup, Noble metal nanoparticles for water purification: A critical review, Thin Solid Films 517 (2009) 6441-6478.

[5] X. Zhang, S. Lin, X.-Q. Lu, Z. Chen, Removal of $\mathrm{Pb}$ (II) from water using synthesized kaolin supported nanoscale zero-valent iron, Chem. Eng. J. 163 (2010) 243-248.

[6] A. Uheida, M. Iglesias, C. Fontàs, M. Hidalgo, V. Salvadó, Y. Zhang, M. Muhammed, Sorption of palladium(II), rhodium(III), and platinum(IV) on $\mathrm{Fe}_{3} \mathrm{O}_{4}$ nanoparticles, J. Colloid Interface Sci. 301 (2006) 402-408.

[7] N. Strigul, L. Vaccari, C. Galdun, M. Wazne, X. Liu, C. Christodoulatos, K. Jasinkiewicz, Acute toxicity of boron, titanium dioxide, and aluminum nanoparticles to Daphnia magna and Vibrio fischeri, Desalination 248 (2009) 771-782.

[8] R. Owen, R. Handy, Formulating the problems for environmental risk assessment of nanomaterials, Environ. Sci. Technol. 41 (2007) 5582-5588.

[9] R. Behra, H. Krug, Nanoecotoxicology: Nanoparticles at large, Nat. Nanotechnol. 3 (2008) 253-254.

[10] R. Zhang, Y. Niu, Y. Li, C. Zhao, B. Song, Y. Li, Y. Zhou, Acute toxicity study 
of the interaction between titanium dioxide nanoparticles and lead acetate in mice, Environ. Toxicol. Pharmacol. 30 (2010) 52-60.

[11] K. Hund-Rinke, M. Simon, Ecotoxic effect of photocatalytic active nanoparticles $\left(\mathrm{TiO}_{2}\right)$ on algae and daphnids, Environ. Sci. Pollut. Res. 13 (2006) $225-232$.

[12] Nanotechnology white paper. Document Number EPA 100/B-07001 1 February 2007, United States Environmental Protection Agency.

[13] M. Ruffini, Castiglione, R. Cremonini, Nanoparticles and higher plants, Caryologia 62 (2009) 161-165.

[14] J. Turkevich, P.C. Stevenson, J. Hillier, Nucleation and growth process in the synthesis of colloidal gold, J. Discuss. Faraday Soc. 11 (1951) 55-75.

[15] F. Zhang, Q. Jin, S.W Chan, Ceria nanoparticles: Size, size distribution, and shape, J. Appl. Phys. 95 (2004) 4319-4326.

[16] A. Pottier, S. Cassaignon, C. Chaneac, F. Villain, E. Tronca, J.P. Jolivet, Size tailoring of $\mathrm{TiO}_{2}$ anatase nanoparticles in aqueous medium and synthesis of nanocomposites. Characterization by Raman spectroscopy, J. Mater. Chem. 13, (2003) 877-882.

[17] R. Massart, Preparation of Aqueous Magnetic Liquids in Alkaline and Acidic Media, IEEE Transactions on Magnetics. 17 (1981) 1247-1248.

[18] J.P. Jolivet, R. Massart, J.M. Fruchart, Synthesis and physicochemical study on nonsurfactant magnetic colloids in aqueous medium, Nouveau J. De ChimieNew J. Chem. 7 (1983) 325-331.

[19] A. Greenberg, J. Connors, D. Jenkins, Standard methods for the examination of water and wastewater. 15th ed. American Public Health Association, USA. 1981, pp. 187-190. 
[20] N. Nashaat, N. Nassar, Rapid removal and recovery of $\mathrm{Pb}$ (II) from wastewater by magnetic nanoadsorbents, J. Hazard. Mater. 184 (2010) 538-546.

[21] A. Uheida, M. Iglesias, C. Fontàs, M. Hidalgo, V. Salvadó, Y. Zhang, M. Muhammed, Sorption of palladium(II), rhodium(III), and platinum(IV) on $\mathrm{Fe}_{3} \mathrm{O}_{4}$ nanoparticles, J. Colloid Interface Sci. 301 (2006) 402-408.

[22] A. Uheida, G. Salazar-Alvarez, E. Björkman, Z. Yu, M. Muhammed, $\mathrm{Fe}_{3} \mathrm{O}_{4}$ and $\mathrm{g}-\mathrm{Fe}_{2} \mathrm{O}_{3}$ nanoparticles for the adsorption of $\mathrm{Co}^{2+}$ from aqueous solution, J. Colloid Interface Sci. 298 (2006) 501-507.

[23] H. Sun, X. Zhang, Q. Niu, Y. Chen, J. Crittenden, Enhanced accumulation of arsenate in carp in the presence of titanium dioxide nanoparticles, Water Air Soil Pollut. 178 (2007) 245-254.

[24] R. Barrena, E. Casals, J. Colón, X. Font, A. Sánchez, V. Puntes, Evaluation of model nanoparticles eco-toxicity, Chemosphere 75 (2009) 850-857.

[25] DIN 38412, part 34, 1991. Determination of the inhibitory effect of wastewater on the light emission of Photobacterium phosphoreum (test using preserved luminescent bacteria).

[26] R.N. Coleman, A.A.Q. Qureshi, Microtox and spirillum volutans tests for assessing toxicity of environmental samples, Bull. Environ. Contam. Toxicol. 35 (1985) 443-451.

[27] DIN 38414, 1987. Bestimmung des faulverhaltens (S8). In: Fachgruppe Wasserchemie in der Gesellschaft Deutscher Chemiker und Normausschuss Wasserwesen (NAW) im DIN Deutsches Institut für Normung e.V. (Eds.), Deutsche Einheitsverfahren zur Wasser-, Abwasser- und Schlammuntersuchung, Physikalische, chemische, biologische und bakteriologische Verfahren, VCH Verlagsgesellschaft mbH, Weinheim, Germany. 
[28] A.K. Pandey, V. Misra, A.K. Srimal, Removal of chromium and reduction of toxicity to Microtox system from tannery effluent by the use of calcium alginate beads containing humic acid, Chemosphere 51 (2003) 329-333.

[29] M.S. Tiquia, N.F.Y. Tam, I.J. Hodgkiss, Effects of composting on phytotoxicity of spent pig-manure sawdust litter, Environ. Pollut. 93 (1996) 249-256.

[30] The US Department of Agriculture and The US Composting Council, Test methods for the examination of composting and compost, Edaphos International, Houston, 2001.

[31] Y-S. Ho, Review of second-order models for adsorption systems, J. Hazar. Mater. B136 (2006) 681-689.

[32] Y.S. Ho, G. McKay, The kinetics of sorption of divalent metal ions onto sphagnum moss peat, Water Res. 34 (2000) 735-742.

[33] X. Xie, L. Gao, Effect of crystal structure on adsorption behaviors of nanosized $\mathrm{TiO}_{2}$ for heavy-metal cations, Appl. Phys. 9 (2009) S185-S188.

[34] X. Zhao, Q. Jia, N. Song, W. Zhou, Y. Li, Adsorption of Pb(II) from an Aqueous Solution by Titanium Dioxide/Carbon Nanotube Nanocomposites: Kinetics, Thermodynamics and Isotherms, J. Chem. Eng. Data, 55 (2010) 44284433.

[35] R.J. Griffitt, J. Luo, J. Gao, J.C. Bonzongo, D.S. Barber, Effects of particle composition and species on toxicity of metallic nanomaterials in aquatic organisms, Environ. Toxicol. Chem. 27 (2008) 1972-1978.

[36] M. Heinlaan, A. Ivask, I. Blinova, H.-C. Dubourguier, A. Kahru, Toxicity of nanosized and bulk $\mathrm{ZnO}, \mathrm{CuO}$ and $\mathrm{TiO}_{2}$ to bacteria Vibrio fischeri and crustaceans Daphnia magna and Thamnocephalus platyurus, Chemosphere, 71 (2008) 1308-1316. 
[37] P. Pärt, G. Wilmark, The influence of some complexing agents (EDTA and Citrate) on the uptake of cadmium in the perfused rainbow trout gills, Aquat. Toxicol. 5 (1984) 277-289.

[38] D.E. Giammar, C.J. Maus, L. Xie, Effects of Particle Size and Crystalline Phase on Lead Adsorption to Titanium Dioxide Nanoparticles, Environ. Eng. Sci. 24, (2007) 85-95.

[39] A.T. Stone, A. Torrents, J. Smolen, D. Vasudevan, J. Hadley, Adsorption of organic-compounds possessing ligand donor groups at the oxide water interface, Environ. Sci. Technol. 27, (1993) 895-909.

[40] M. Racuciu, D. Creanga, TMA-OH coated magnetic nanoparticles internalized in vegetal tissue, Rom. J. Phys. 52 (2007) 395-402.

[41] M.L. Lopez-Moreno, G. De La Rosa, J.A. Hernandez-Viezcas, J.R. PeraltaVidea, J.L. Gardea-Torresdey, X-ray Absorption Spectroscopy (XAS) Corroboration of the Uptake and Storage of $\mathrm{CeO}_{2}$ Nanoparticles and Assessment of Their Differential Toxicity in Four Edible Plant Species, J. Agric. Food Chem. 58 (2010) 3689-3693. 
Tables

Table 1. Main characteristics of the used nanoparticles as they were synthesized.

\begin{tabular}{|c|c|c|c|c|c|c|}
\hline $\begin{array}{l}\text { Nanoparticle } \\
\text { composition }\end{array}$ & Shape & $\begin{array}{c}\text { Z- } \\
\text { Potential } \\
(\mathbf{m V})\end{array}$ & $\begin{array}{l}\text { Surface } \\
\text { coating }\end{array}$ & $\begin{array}{c}\text { Concentration } \\
(\mathrm{NPs} / \mathrm{mL})\end{array}$ & $\begin{array}{c}\text { Concentration } \\
(\mathrm{mg} / \mathrm{mL})\end{array}$ & $\begin{array}{c}\begin{array}{c}\text { Solvent } \\
\text { Conc. } \\
(\mathbf{m M})\end{array} \\
\end{array}$ \\
\hline $\begin{array}{l}\text { Iron Oxide } \\
\qquad\left(\mathrm{Fe}_{3} \mathrm{O}_{4}\right)\end{array}$ & Irregular & -58 & $\begin{array}{l}\text { Inorganic } \\
\text { TMAOH* }^{*}\end{array}$ & $\sim 10^{15}$ & 0.67 & $\begin{array}{c}\text { TMAOH } \\
1\end{array}$ \\
\hline $\begin{array}{l}\text { Cerium } \\
\text { Oxide } \\
\left(\mathrm{CeO}_{2}\right)\end{array}$ & Irregular & +12 & $\begin{array}{c}\text { Inorganic } \\
\text { HMT* }^{*}\end{array}$ & $\sim 10^{16}$ & 0.64 & $\begin{array}{c}\text { HMT } \\
8.33\end{array}$ \\
\hline $\begin{array}{c}\text { Titanium } \\
\text { Oxide } \\
\left(\mathrm{TiO}_{2}\right)\end{array}$ & Irregular & -42 & $\begin{array}{l}\text { Inorganic } \\
\text { TMAOH* }^{*}\end{array}$ & $\sim 10^{16}$ & 1.2 & $\begin{array}{c}\text { TMAOH } \\
10\end{array}$ \\
\hline
\end{tabular}

* TMAOH: Tetramethylammonium hydroxide

* HMT: Hexamethylenetetramine 
Table 2. Adsorption capacity (mg $\mathrm{Pb}^{2+} / \mathrm{g}$ NPs) after 24 hours of reaction, $\mathrm{Pb}^{2+}$ removal (\%) and equilibrium $\mathrm{Pb}^{2+}$ concentration (mg/l) of $\mathrm{CeO}_{2}, \mathrm{TiO}_{2}$ and $\mathrm{Fe}_{3} \mathrm{O}_{4} \mathrm{NPs}$.

\begin{tabular}{|c|c|c|c|c|c|}
\hline NPs & $\begin{array}{c}\mathrm{Pb}^{2+} \\
\text { Initial } \\
\text { conc. } \\
(\mathrm{mg} / \mathrm{l}) \\
\end{array}$ & $\begin{array}{c}\text { NPs } \\
\text { concentration } \\
(\mathbf{m g} / \mathbf{l})\end{array}$ & $\begin{array}{c}\mathbf{P b}^{2+} \\
\text { equilibrium } \\
\text { conc. } \\
\text { (mg/l) }\end{array}$ & $\begin{array}{c}\mathrm{q}(\mathrm{t}) 24 \mathrm{~h} \\
(\mathrm{mg} \mathrm{Pb} / \mathrm{g} \text { NPs) }\end{array}$ & $\begin{array}{c}\mathrm{Pb}^{2+} \\
\text { removal } \\
(\%)\end{array}$ \\
\hline $\mathrm{CeO}_{2}$ & 3.4 & 320 & N.D* & 10.3 & $\sim 100$ \\
\hline $\mathrm{CeO}_{2}$ & 8.5 & 320 & N.D* & 26.6 & $\sim 100$ \\
\hline $\mathrm{CeO}_{2}$ & 17 & 320 & 3.9 & 41.0 & 77.3 \\
\hline $\mathrm{CeO}_{2}$ & 95 & 320 & 37.0 & 181.2 & 58 \\
\hline $\mathrm{TiO}_{2}$ & 3.4 & 560 & N.D* & 6.1 & $\sim 100$ \\
\hline $\mathrm{TiO}_{2}$ & 8.5 & 560 & 4.2 & 7.8 & 51.1 \\
\hline $\mathrm{TiO}_{2}$ & 17 & 560 & 10.8 & 11.0 & 36.2 \\
\hline $\mathrm{TiO}_{2}$ & 95 & 320 & 64.8 & 153.2 & 49.2 \\
\hline $\mathrm{Fe}_{3} \mathrm{O}_{4}$ & 3.4 & 335 & N.D* & 10.1 & $\sim 100$ \\
\hline $\mathrm{Fe}_{3} \mathrm{O}_{4}$ & 8.5 & 335 & N.D* & 25.4 & $\sim 100$ \\
\hline $\mathrm{Fe}_{3} \mathrm{O}_{4}$ & 17 & 335 & N.D* & 50.7 & $\sim 100$ \\
\hline $\mathrm{Fe}_{3} \mathrm{O}_{4}$ & 95 & 320 & 68.9 & 81.6 & 26.1 \\
\hline
\end{tabular}

* N.D: not detected 
Table 3. Maximum adsorption capacity at equilibrium and pseudo-second-order rate constants $\left(k_{2}\right)$ obtained using the pseudo-second-order kinetic model. Concentration of NPs of $\mathrm{CeO}_{2}, \mathrm{Fe}_{3} \mathrm{O}_{4}$ and $\mathrm{TiO}_{2}$ was $320 \mathrm{mg} / \mathrm{l}$ and initial $\mathrm{Pb}^{2+}$ concentration was 100 $\mathrm{mg} / \mathrm{l}$.

\begin{tabular}{lcccc}
\hline NPs & $\begin{array}{c}\text { Concentration } \\
(\mathrm{mg} / \mathrm{l})\end{array}$ & $\begin{array}{c}\mathrm{q}_{\mathrm{e}} \\
\left(\mathrm{mgPb}^{2+} / \mathrm{g} \mathrm{NPs}\right)\end{array}$ & $\begin{array}{c}k_{2} \\
\left(\mathrm{~g} \mathrm{CeO}_{2} /\left(\mathrm{mg} \mathrm{Pb}^{2+} \mathrm{h}\right)\right)\end{array}$ & $\mathrm{R}^{2}$ \\
\hline $\mathrm{CeO}_{2}$ & 320 & 188.70 & 0.035 & 0.991 \\
$\mathrm{Fe}_{3} \mathrm{O}_{4}$ & 320 & 82.64 & 0.012 & 0.986 \\
$\mathrm{TiO}_{2}$ & 320 & 158.73 & 0.004 & 0.982 \\
\hline
\end{tabular}


Table 4. The IC50 obtained by Microtox assay at 15 minutes for $\mathrm{Fe}_{3} \mathrm{O}_{4}, \mathrm{CeO}_{2}$ and $\mathrm{TiO}_{2}$ NPs, NPs oxides with lead adsorbed $\left(2.5 \mathrm{mg} / \mathrm{Pb}^{2+}\right)$ and the liquor obtained when NPs with lead adsorbed was centrifuged.

\begin{tabular}{|c|c|}
\hline Compound & IC50 \\
\hline NPs Fe & 44.8 \\
\hline $\mathrm{NPs} F e+\mathrm{Pb}$ & 50.5 \\
\hline Liquor NPs Fe & 163.2 \\
\hline NPs Ce & 35.2 \\
\hline $\mathrm{NPs} \mathrm{Ce}+\mathrm{Pb}$ & 38.7 \\
\hline Liquor NPs Ce & 35.7 \\
\hline NPs Ti & no toxic \\
\hline $\mathrm{NPs} \mathrm{Ti}+\mathrm{Pb}$ & no toxic \\
\hline Liquor NPs Ti & no toxic \\
\hline $\begin{array}{l}\text { Initial } \mathrm{Pb} \text { solution } \\
\left(2.5 \mathrm{mg} / \mathrm{l} \mathrm{Pb}^{2+}\right)\end{array}$ & 0.1 \\
\hline
\end{tabular}


Table 5. Influence of nanoparticle samples on germination index (GI) and root growth for Lettuce (Lactuca sativa), Tomato (Lycopersicom esculentum) and Cucumber (Cucumis sativus) seeds. Significant difference was marked with asterisk $\left(^{*}\right)(\mathrm{p} \leq 0.05)$.

\begin{tabular}{|c|c|c|c|c|c|c|}
\hline \multirow[b]{2}{*}{ Species } & \multicolumn{2}{|c|}{$\mathrm{Fe}_{3} \mathrm{O}_{4} \mathrm{NPs}$} & \multicolumn{2}{|c|}{$\mathrm{TiO}_{2} \mathrm{NPs}$} & \multicolumn{2}{|c|}{$\mathrm{CeO}_{2} \mathrm{NPs}$} \\
\hline & $\begin{array}{l}\text { GI } \\
(\%)\end{array}$ & $\begin{array}{c}\text { Root } \\
\text { elongation } \\
(\%)\end{array}$ & $\begin{array}{l}\text { GI } \\
(\%)\end{array}$ & $\begin{array}{c}\text { Root } \\
\text { elongation } \\
(\%)\end{array}$ & $\begin{array}{l}\text { GI } \\
(\%)\end{array}$ & $\begin{array}{c}\text { Root } \\
\text { elongation } \\
(\%)\end{array}$ \\
\hline \multicolumn{7}{|l|}{ Lettuce } \\
\hline $\begin{array}{l}\text { Distilled } \\
\text { water }\end{array}$ & $97 \pm 3$ & $100 \pm 0$ & $97 \pm 3$ & $100 \pm 0$ & $97 \pm 3$ & $100 \pm 0$ \\
\hline Solvent & $61 \pm 1^{*}$ & $67 \pm 2^{*}$ & $88 \pm 12$ & $91 \pm 7$ & $75 \pm 7^{*}$ & $82 \pm 5^{*}$ \\
\hline $\begin{array}{c}\text { Solvent }+ \\
\text { Lead }\end{array}$ & $64 \pm 3^{*}$ & $74 \pm 11^{*}$ & $74 \pm 9^{*}$ & $77 \pm 5^{*}$ & $74 \pm 5^{*}$ & $76 \pm 3^{*}$ \\
\hline NPs & $84 \pm 5$ & $89 \pm 4^{*}$ & $97 \pm 10$ & $104 \pm 4$ & $4 \pm 1^{*}$ & $4 \pm 7^{*}$ \\
\hline NPs-Pb & $94 \pm 9$ & $108 \pm 3$ & $105 \pm 1$ & $107 \pm 3^{*}$ & $4 \pm 1^{*}$ & $5 \pm 1^{*}$ \\
\hline $\begin{array}{l}\text { NPs-Pb } \\
\text { liquor }\end{array}$ & $106 \pm 10$ & $112 \pm 13$ & $98 \pm 17$ & $105 \pm 19$ & $2 \pm 1^{*}$ & $3 \pm 1^{*}$ \\
\hline \multicolumn{7}{|l|}{ Tomato } \\
\hline $\begin{array}{l}\text { Distilled } \\
\text { water }\end{array}$ & $87 \pm 3$ & $100 \pm 0$ & $87 \pm 3$ & $100 \pm 0$ & $87 \pm 3$ & $100 \pm 0$ \\
\hline Solvent & $42 \pm 12^{*}$ & $46 \pm 10^{*}$ & $62 \pm 4 *$ & $64 \pm 3^{*}$ & $51 \pm 10^{*}$ & $526 \pm 7^{*}$ \\
\hline $\begin{array}{c}\text { Solvent + } \\
\text { Lead }\end{array}$ & & $43+2 *$ & $47 \pm 3^{*}$ & $52 \pm 1^{*}$ & $74 \pm 24$ & $88 \pm 17$ \\
\hline NPs & $61 \pm 3^{*}$ & $66 \pm 4^{*}$ & $85 \pm 16$ & $97 \pm 10$ & $5 \pm 1^{*}$ & $5 \pm 2^{*}$ \\
\hline NPs -Pb & $67 \pm 15$ & $69 \pm 12^{*}$ & $78 \pm 11$ & $90 \pm 11$ & $2 \pm 0^{*}$ & $4 \pm 0$ * \\
\hline $\begin{array}{c}\text { NPs-Pb } \\
\text { liquor }\end{array}$ & $81 \pm 8$ & $87 \pm 6$ & $84 \pm 7$ & $101 \pm 18$ & $2 \pm 0^{*}$ & $4 \pm 0$ * \\
\hline \multicolumn{7}{|l|}{ Cucumber } \\
\hline $\begin{array}{c}\text { Distilled } \\
\text { water }\end{array}$ & $97 \pm 6$ & $100 \pm 0$ & 976 & $100 \pm 0$ & $97 \pm 6$ & $100 \pm 0$ \\
\hline Solvent & $76 \pm 16$ & $88 \pm 19$ & $103 \pm 14$ & $111 \pm 21$ & $63 \pm 14$ & $70 \pm 9$ \\
\hline $\begin{array}{c}\text { Solvent + } \\
\text { Lead }\end{array}$ & $81 \pm 14$ & $86 \pm 10$ & $86 \pm 12$ & $88 \pm 8$ & $72 \pm 12$ & $72 \pm 12$ \\
\hline NPs & $78 \pm 10$ & $82 \pm 16$ & $103 \pm 16$ & $107 \pm 18$ & $1 \pm 0 *$ & $2 \pm 0^{*}$ \\
\hline $\begin{array}{c}\mathrm{Fe}_{3} \mathrm{O}_{4}-\mathrm{Pb} \\
\mathrm{NPs}\end{array}$ & $96 \pm 22$ & $99 \pm 19$ & $91 \pm 9$ & $94 \pm 9$ & $2 \pm 1^{*}$ & $2 \pm 1^{*}$ \\
\hline $\begin{array}{c}\mathrm{Fe}_{3} \mathrm{O}_{4}-\mathrm{Pb} \\
\mathrm{NPs} \\
\text { liquor }\end{array}$ & $95 \pm 12$ & $98 \pm 8$ & $109 \pm 21$ & $116 \pm 20$ & $2 \pm 0^{*}$ & $2 \pm 1^{*}$ \\
\hline
\end{tabular}




\section{Legends to Figures}

Figure 1.- Characterization of the NPs used in this work. Left: TEM image and size distribution (inset) and right: XRD spectrum, as characteristic signatures of these NPs.

Figure 2.- $\mathrm{Pb}^{2+}$ adsorption evolution at $\mathrm{pH}=7$ and room temperature. $\mathrm{Fe}_{3} \mathrm{O}_{4}$ (square), $\mathrm{CeO}_{2}$ (circle) and $\mathrm{TiO}_{2}$ (triangle). Initial $\mathrm{Pb}$ concentration was $95 \mathrm{mg} / \mathrm{l}$ and initial concentration of NPs was $320 \mathrm{mg} / \mathrm{l}$.

Figure 3.- Pseudo-second-order model: $\mathrm{Pb}^{2+}$ adsorption by $\mathrm{Fe}_{3} \mathrm{O}_{4}$ (squares), $\mathrm{CeO}_{2}$ (circles) and $\mathrm{TiO}_{2}$ (triangles). 
Fig. 1

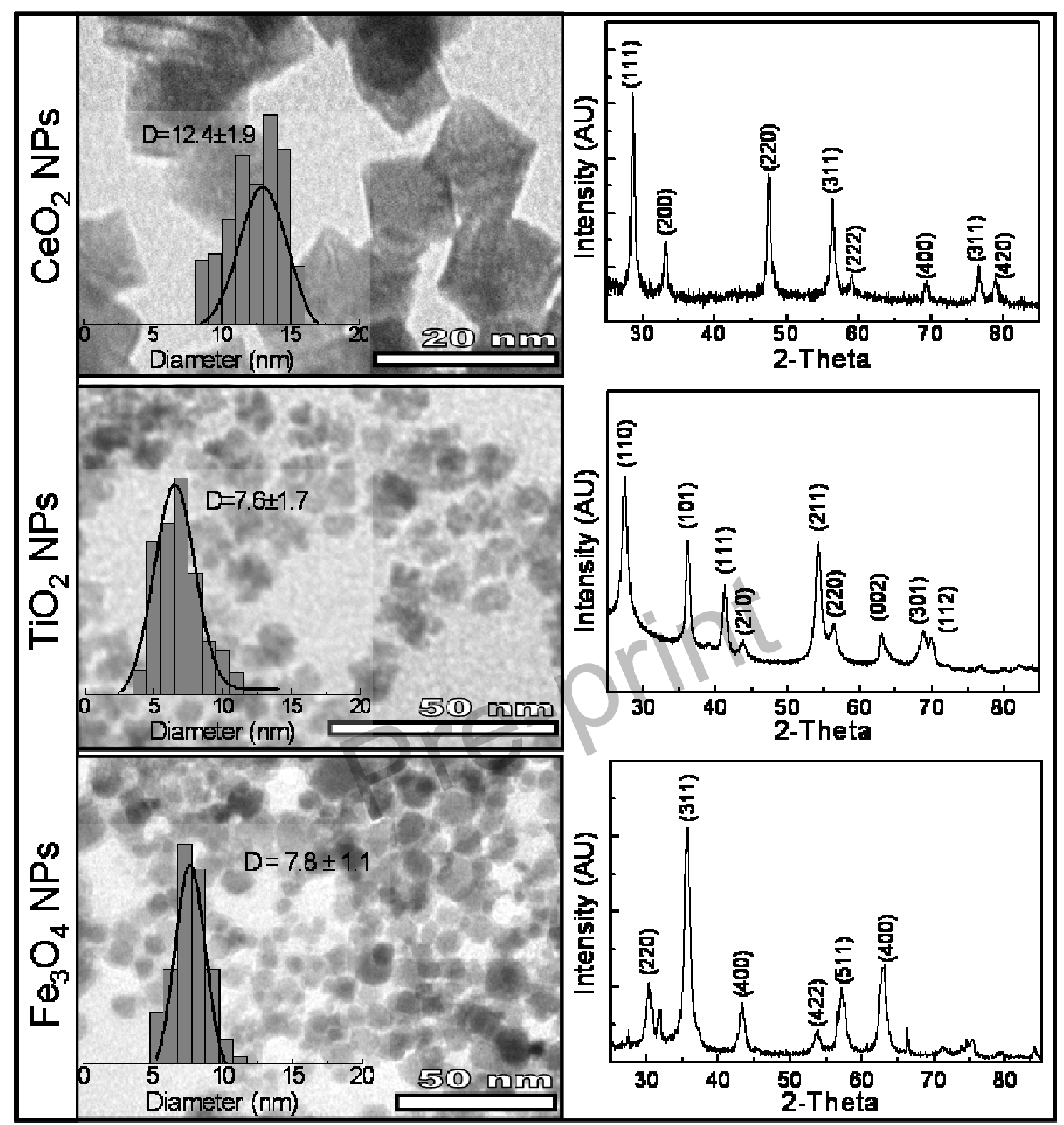


Fig. 2

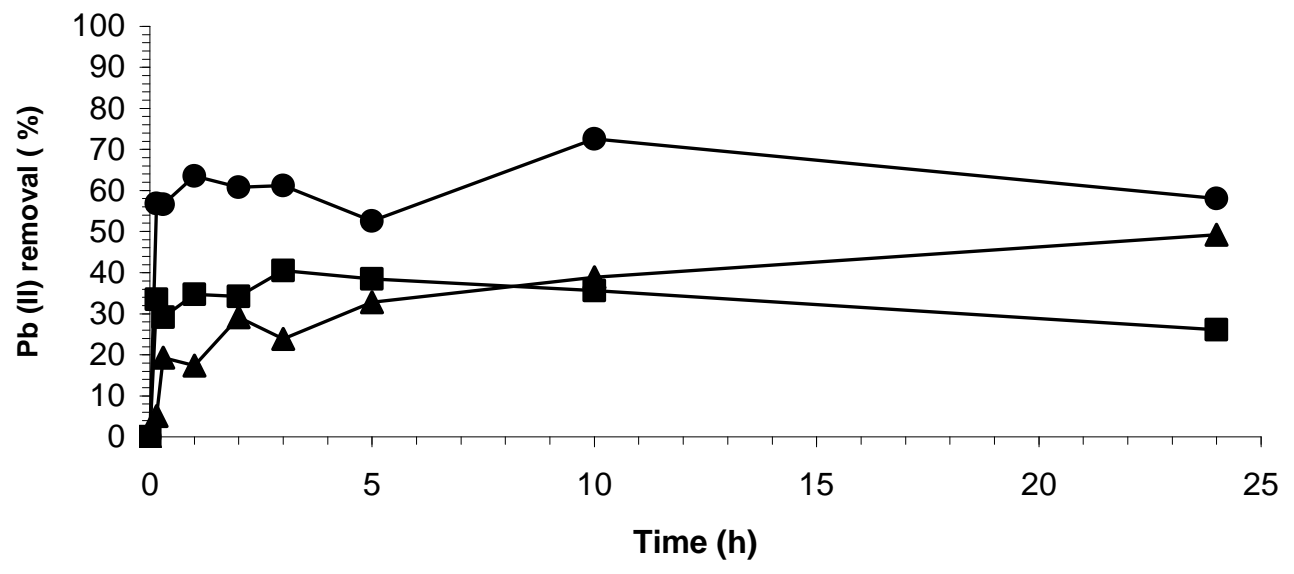


Fig. 3
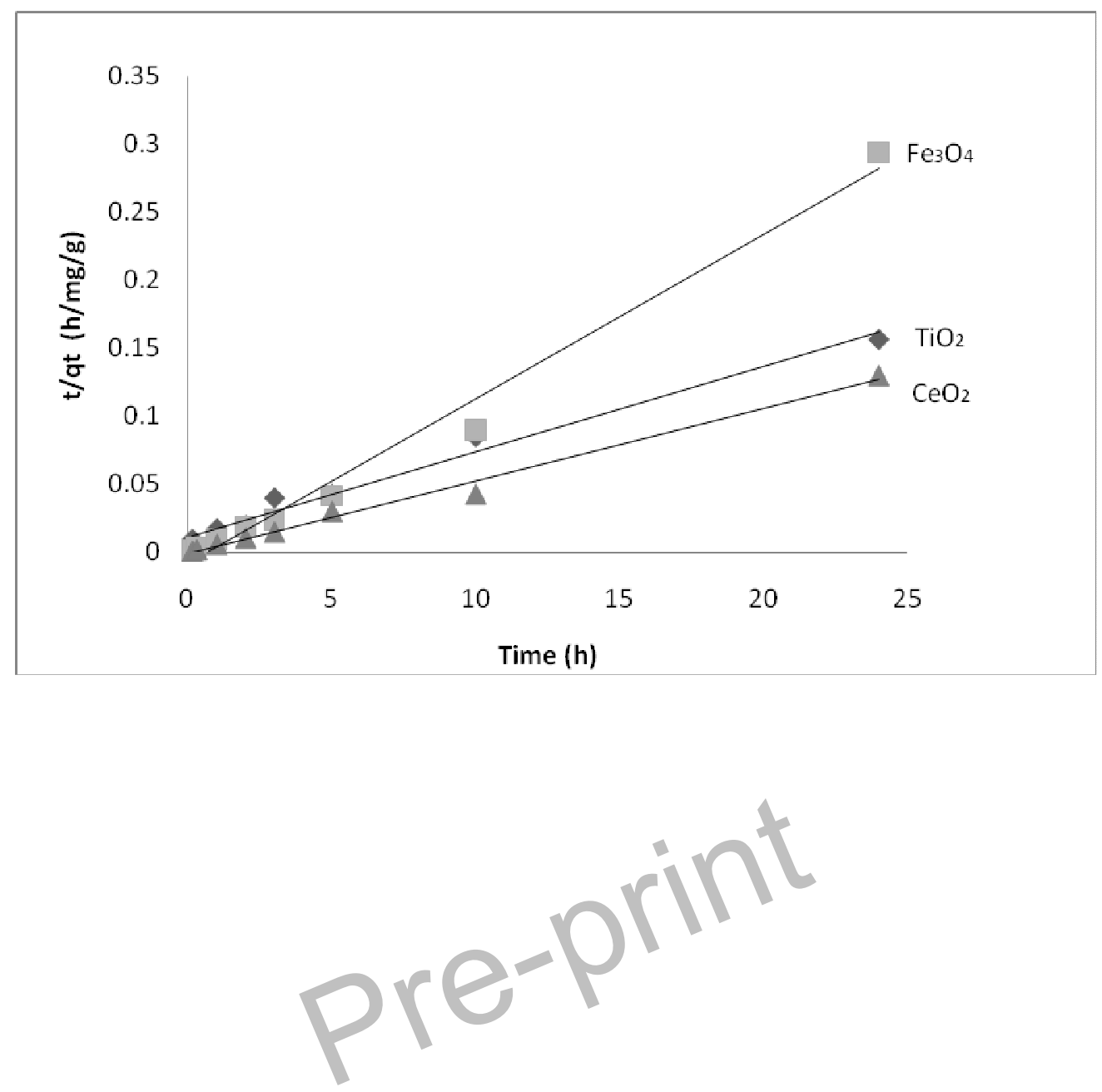